\title{
Records from coastal ice cores
}

\section{Vin MoRgan}

Antarctic Climate and Ecosystems Cooperative Research Centre, and the Ice, Oceans, Atmosphere and Climate Programme, Australian Antarctic Division, Hobart, Australia; vin.morgan@utas.edu.au

\section{Introduction}

Ice cores drilled on the periphery of the Antarctic ice sheet provide environmental records that complement those from deep cores from the interior of the continent. On the high plateau of East Antarctica, isolation from the oceanic moisture sources, low rates of snow accumulation and the great ice thickness allow deep ice cores to provide records of broad scale climate over multiple glacial cycles.

On the coastal slopes and low elevation parts of Antarctica, the more variable geography-surface slope, proximity to the ocean, domes, crests, etc. - and the generally higher accumulation rates and thinner ice results in cores having shorter records but with higher resolution, at least for the recent period. Coastal cores record a more regional signal, particularly through the deglaciation when rising sea level and temperature elicited different responses at different locations on the ice sheet. The dynamic coastal band, with its high accumulation rates and faster ice flow, dominates the annual ice turnover of Antarctica. The mass balance of the coastal ice sheet, and thus its contribution to sea level change, can respond rapidly to climatic change but at the same time, the slow response time of the inland ice sheet (which is coupled to the coastal ice by ice flow) means that the ice sheet as a whole is still adjusting to the temperature and sea level changes of the last deglaciation. We know from existing records (see examples in Fig. 1) that different parts Last Glacial Maximum.

\begin{tabular}{|l|l|l|c|c|}
\hline $\begin{array}{l}\text { Core } \\
\text { Location }\end{array}$ & Study area & Drilling period & $\begin{array}{l}\text { Depth to } \\
\text { bedrock (m) }\end{array}$ & $\begin{array}{l}\text { Time period } \\
\text { covered (yrs) }\end{array}$ \\
\hline Berkner Island & Weddell Sea & $2002-2005$ & 949 & $\sim 50,000$ \\
\hline Byrd & WestAntarctica & 1968 & 2164 & $\sim 100,000$ \\
\hline LawDome & EastAntarctica & $1989-93$ & 1196 & $\sim 90,000$ \\
\hline Siple Dome & WestAntarctica & completed1999 & 1003 & $\sim 90,000$ \\
\hline Talos Dome & Ross Sea & $2005-07$ & $\sim 1500$ & $\sim 120,000$ \\
\hline Taylor Dome & Ross Sea & completed 1994 & 554 & $\sim 230,000$ \\
\hline
\end{tabular}

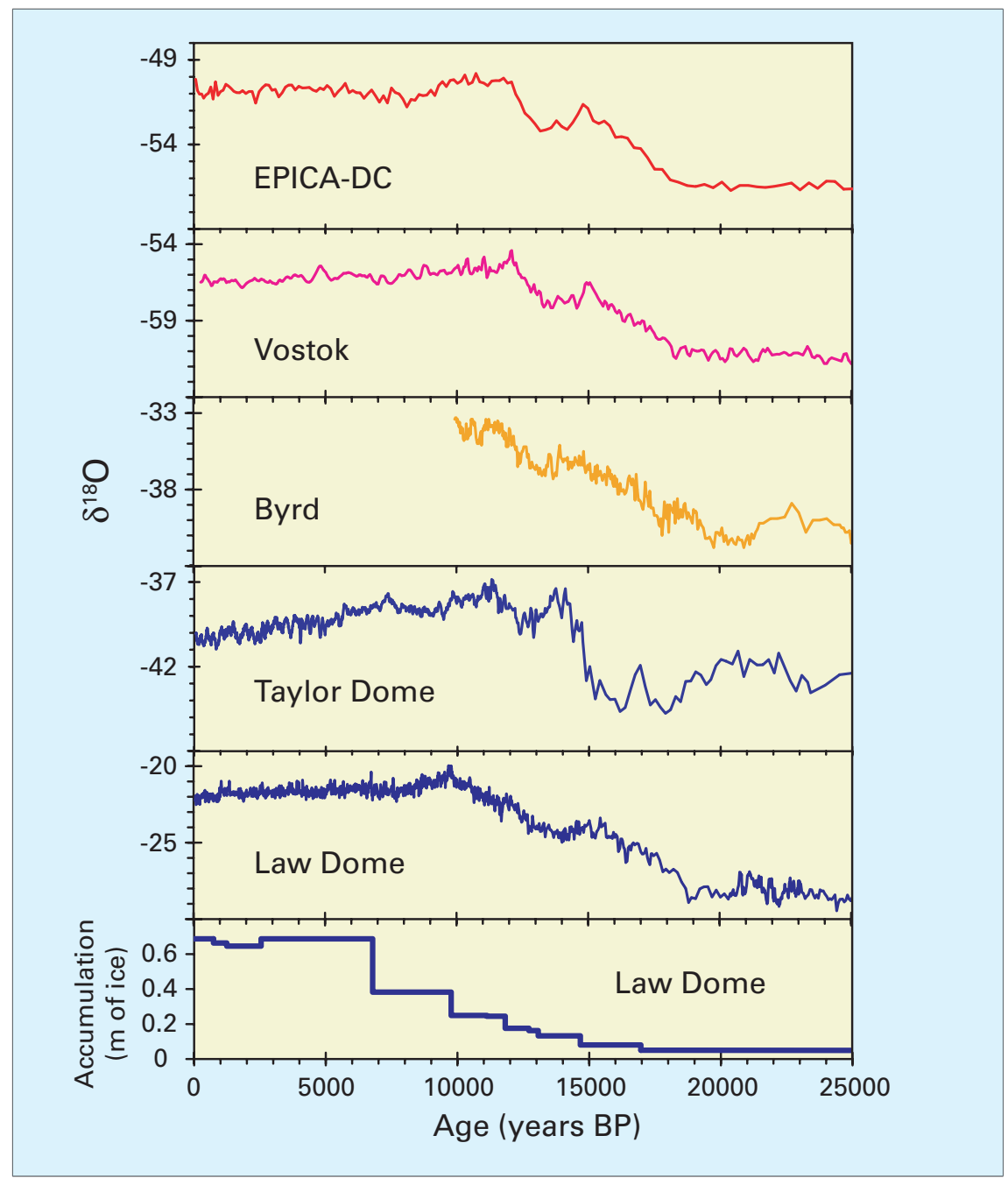

Fig. 1: Isotope records from two inland sites, EPICA-DC and Vostok, two coastal sites, Taylor Dome and Law Dome, and the Byrd record from West Antarctica. Also shown is Law Dome accumulation inferred from the dating model (van Ommen et al., 2004). Within dating errors, EDC and Vostok show a similar pattern. Law Dome shows a similar pattern to the inland cores from the LGM through the ACR but the $\delta^{18} \mathrm{O}$ increase is interrupted by a small dip at 11,500 $B P$ (close in time to the end of the Younger Dryas) and after the dip the increase continues until 10,000, about 2000 years after the inland cores. The Taylor Dome record, shown on the st9810 timescale, differs markedly from the others, showing cold glacial conditions continuing as late as 16,000, a later temperature reversal and continued warming through the Holocene. However, recent results (including isotope ratios of trapped atmospheric nitrogen) suggest there were periods during the deglaciation of little or no accumulation at Taylor Dome.

of the ice sheet have responded differently to the sea level and climate

cores that reach (or are expected to reach) the bution to sea level change, we need additional records from the coastal zone. Accordingly, drilling and analyzing of coastal Antarctic cores has become a major task in ice core research (for a list of some of the most important coastal Antarctic cores see Table 1)

Here we look at two results from the coastal Law Dome ice core. Both 


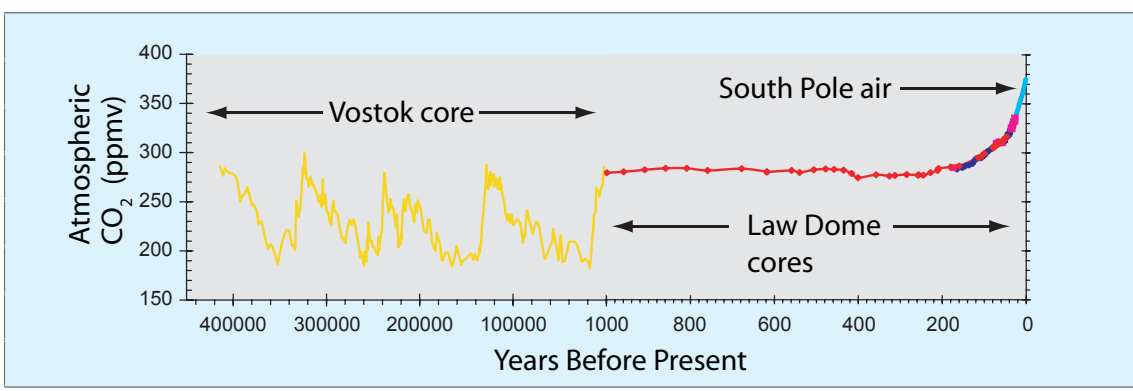

Fig. 2: Composite atmospheric $\mathrm{CO}_{2}$ concentration from 400,000 BP to $1978 \mathrm{AD}$. 400,000 BP to 2300 BP from Vostok (yellow line, Petit et al., 1999) 1000 BP to 1978 AD from the DSS, DE08 and DE08/2 Law Dome cores (Etheridge et al., 1996). 1978 AD to 2004 from South Pole air samples (Keeling and Whorf, 2005). DSS - red line, DE08 - blue line, DE08/2 - violet points, South Pole air - blue line.

involve the high accumulation rate at the core site as a key parameter.

\section{The coastal accumulation regime}

Under present day conditions, accumulation on the inland plateau is mainly in the form of "diamond dust" - clear sky ice crystal precipitation, principally in winter, that results from cooling of the atmosphere by radiative loss. The low air temperature limits available moisture, so inland accumulation rates are low and tend to follow temperature variation. On the coastal slopes, snowfall resulting from orographic uplift of moist air from cyclonic systems results in high accumulation rates that depend mainly on the frequency of cyclones and are largely independent of temperature.

Law Dome projects out from the coast of East Antarctica and is the most northerly part of the continent, apart from the extremity of the Antarctic Peninsula. Under present day meteorology, Law Dome receives precipitation from cyclonic systems, however, recent results (van Ommen et al., 2004) have shown that during the Glacial and through the early Holocene, accumulation rates were only some $10 \%$ of present day and varied with temperature. A similar situation appears to have existed at Taylor Dome, which also has a large accumulation rate change from the Glacial to the Holocene (Steig and others, 2000). It seems that during the Glacial, lower temperatures, more northerly paths of cyclonic systems and the ice sheet expansion allowed by lowered sea level resulted in a shift of the boundary between the inland clear-sky ice-crystal mode of precipitation and the coastal cy- clonic mode to the north of Law Dome. Determining how, when and if this change occurred at different locations is necessary because different precipitation mechanisms can change the calibration of the ice core recorder.

Further work using additional cores to determine the timing and the extent of this change in accumulation mechanism will give insights into changes in Antarctic climate and its possible effects on the ice sheet's mass balance. So far, the only coastal cores that have accumulation records extending into the Glacial are Law Dome and Taylor Dome. In the near future, we expect to be able to add the records from the Berkner Island and Siple Dome cores and in a few years time there will be a record from the new Talos Dome core.

\section{High-resolution gas records}

A feature of the high accumulation coastal cores, and one that is pre-

\section{Project facts}

Project: Deep Ice Drilling on Law Dome Contact: Vin Morgan, vin.morgan@utas.edu.au

Participants: Vin Morgan, Tas van Ommen, Mark Curran, Barbara Smith (Antarctic Climate and Ecosystems Cooperative Research Centre, and the Ice, Oceans, Atmosphere and Climate Programme, Australian Antarctic Division)

Funding: Australian Antarctic Division

Where: Coastal East Antarctica

When: Drilling 1988 to 1993, core analysis ongoing

What: $1200 \mathrm{~m}$ core from surface to bedrock $4.7 \mathrm{~km} \mathrm{SSW}$ of the summit of Law Dome, multiparameter analysis

Database: http://aadc-maps.aad.gov. au/aadc/portal/ www.ncdc.noaa.gov/paleo/icecore/antarctica/law/law.html served despite the layer thinning, is their small delta age values. Delta age is the difference between the age of the air trapped as bubbles in the ice and the age of the surrounding ice, and arises because the air is only trapped when the pores in the firn are closed off to form closed bubbles by the weight of the overlying snow. Close-off occurs around a depth of about $60 \mathrm{~m}$ at Law Dome so to a first approximation-neglecting the limited exchange with the atmosphere near close-off-delta age is the age of the ice at $\sim 60 \mathrm{~m}$. At low accumulation inland sites, delta age can be thousands of years but coastal sites have been found with values as low as 40 years. Figure 2 shows records of atmospheric carbon dioxide concentration from an inland site (Vostok) and a coastal site (Law Dome). Delta age for Vostok is about 2000 years, so the most recent data point is at $2300 \mathrm{BP}$. At DE08 on the eastern flank of Law Dome, the accumulation rate $1.2 \mathrm{~m}$ of ice equivalent per year leads to a delta age of 30 years. The coastal Law Dome site extends the record up to 1978 AD, overlapping direct air composition measurements at South Pole and delineating the increase due to anthropogenic input.

\section{REFERENCES}

Etheridge, D. M., Steele, L. P., Langenfelds, R. B., Francey, R. J., Barnola, J-M. and Morgan, V. I., 1996: Natural and anthropogenic changes in atmospheric $\mathrm{CO}_{2}$ over the last 1000 years from air in Antarctic ice and firn. Journal of Geophysical Research, 101(D2): 4115-4128.

Keeling, C.D. and Whorf, T.P., 2005: Atmospheric $\mathrm{CO}_{2}$ records from sites in the $\mathrm{SIO}$ air sampling network. In Trends: A Compendium of Data on Global Change. Carbon Dioxide Information Analysis Center, Oak Ridge National Laboratory, U.S. Department of Energy, Oak Ridge, Tenn., U.S.A

Steig, E.J. and 7 others, 2000: Wisconsinan and Holocene climate history from an ice core at Taylor Dome, Western Ross Embayment, Antarctica. Geogr. Ann., 82A(2-3): 213-235.

Petit, J. R., Jouzel, J., Raynaud, D., Barkov, N.I., Barnola, J.-M., Basile, I., Bender, M., Chappellaz, J., Davis, M., Delaygue, G., Masson-Delmotte, V., Kotlyakov, V.M., Legrand, M., Lipenkov, V.Y., Lorius, C., Pepin, L., Ritz, C., Saltzman, E., and Stievenard M., 1999: Climate and atmospheric history of the past 420,000 years from the Vostok ice core, Antarctica, Nature, 399: 429-436.

van Ommen, T., Morgan, V. and Curran, M., 2004: Deglacial and Holocene changes in accumulation at Law Dome, East Antarctica. Ann. Glaciol., 39: 359-365. 